\title{
Transfer of Organochlorine Pesticide Residues into Cigarette Smoke as a Function of Tobacco Blends and Filter Types*
}

\author{
by P. Ceschini and R. Chauchaix \\ Research Division, Tabacofina S.A., Geneva, Switzerland
}

\section{INTRODUCTION}

To prevent excessive treatment of tobacco plants and crops with pesticides, several countries have prescribed maximum levels for pesticide residues. In view of these legal measures, the laboratories of the industry made a considerable effort to analytically assess pesticide residues in tobacco and in smoke.

By systematically monitoring the leaf crops, it has been established that the trend is towards less pesticide residues in general, and an almost complete absence of those substances the use of which on tobacco crops has been prohibited in the tobacco-producing countries.

Although governmental regulations refer only to the pesticide residues remaining in the manufactured tobacco products $^{* * *}$ (cigarettes, cigars and pipe tobacco), this study investigates the fate of these substances during smoking, in particular their transfer from the tobacco into the smoke, and their retention by commercial cigarette filters.

\section{EXPERIMENTAL}

\section{Objectives of the Study}

a)

Determination of the transfer of pesticides into the smoke from four different types of tobacco blends, keeping constant cigarette paper and filter (cellulose acetate:5.0/ 45,000 Y): American, Maryland, Virginia and Oriental blends.

b)

The effect of filters was tested on American blend cigarettes tipped with the following four types of filters: cellulose filter, cellulose acetate filter I 5.0/45,000 Y, cellulose acetate filter II $2.1 / 36,000 \mathrm{Y}$, and a charcoal filter in the plug-space-plug configuration.

\footnotetext{
* Presented at the 6th International Tobacco Scientific Congress (Coresta) held in Tokyo, Japan, in Norember 1976.

Received: 31st August 1977 - accepted: 8th November 1979.

* Except for Yugoslav government, which refers to pesticide residues in tobacco smoke.
}

\section{Flgure 1. Definition of terms.}

A: Amount of pesticides in the tobacco filler to be smoked.

B: Amount of pestlcides in the tobacco part of the clgarette butt.

F: Amount of pesticides in the smoke retained by the cigarette filter. C: Amount of pesticides in the smoke retained by the Cambridge filter
pad.

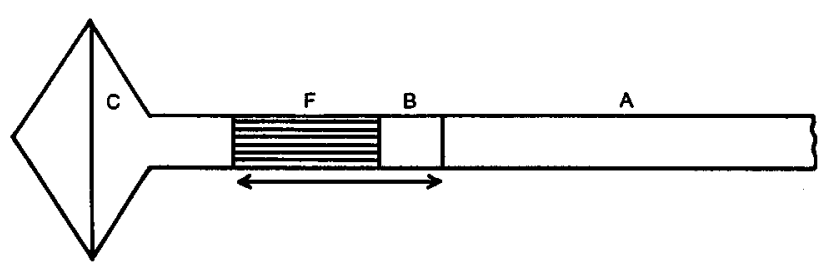

Transfer Rates ( $\mathrm{T}$ )

Transfer into cigarette filter:

$$
\mathrm{T}_{\mathrm{F}}=100 \frac{\mathrm{F}}{\mathrm{A}} \quad[\%]
$$

Transfer into mainstream smoke:

$$
\mathrm{T}_{\mathrm{C}}=100 \frac{\mathrm{C}}{\mathrm{A}} \quad[\%]
$$

Total transfer:

$$
\mathrm{T}_{\mathrm{t}}=100 \frac{\mathrm{F}+\mathrm{C}}{\mathrm{A}}=\mathrm{T}_{\mathrm{F}}+\mathrm{T}_{\mathrm{C}}
$$

Pesticide retention $(\mathrm{R})$ by the filter:

$$
\mathrm{R}_{\mathrm{F}}=100 \frac{\mathrm{F}}{\mathrm{F}+\mathrm{C}} \quad[\%]
$$

\section{Extraction}

The pesticides were extracted and determined according to the Coresta + Recommended Method No. 2 relating to the determination of organochlorine pesticide residues in the tobacco $(2 a, 2 b, 4)$. The cigarettes all had a total length of $85 \mathrm{~mm}$, with a $20 \mathrm{~mm}$ filter. They were conditioned,

+ Cooperation Centre for Scientific Research Relative to Tobacco, Paris. 
selected on a weight and pressure drop basis and smoked according to the Coresta Standard Method Nr. 10 (1) on a Borgwaldt RM 20/CS smoking machine. The smoke was trapped on a $92 \mathrm{~mm}$ diameter Cambridge filter disc. In one instance, when the retention of nicotine by the charcoal filter had to be determined, the direct Coresta Standard Method No. 13 (3) was used.

The pesticides were extracted separately from the Cambridge disc and the cigarette filter $(5,10,11)$. Because of the very low quantities of pesticides to be dealt with in cigarette smoke, 20,40 or 60 cigarettes had to be smoked to determine all those pesticides that had been found in the tobacco.

The final determination of the pesticides was performed by gas chromatography under the following conditions:

Gas chromatograph: Hewlett-Padkard 5750

Detector:

Electron capture $\mathrm{Ni}-63$

Column:

Glass, $4 \mathrm{~m} \times 2 \mathrm{~mm}(1.5 \%$ SP-2250 $+1.95 \%$ SP-2400/Supelco, 100120 mesh)

Temperatures:

Injector: $225^{\circ} \mathrm{C}$

Detector: $270^{\circ} \mathrm{C}$

Column: $205^{\circ} \mathrm{C}$ (isothermal)

Carrier gas:

Helium (40 ml/min)

Auxiliary gas:

Argon-methane (90:10): $90 \mathrm{ml} / \mathrm{min}$

Internal standard: Mirex

The following pesticides were studied:

$\alpha-\mathrm{BHC}$

$\gamma$-BHC (lindane)

Aldrin

o, $\mathrm{P}^{\prime}$-DDE

$\alpha$-Endosulfan

p, p'-DDE

Dieldrin

o,p'-TDE

Endrin

o, $\mathrm{P}^{\prime}-\mathrm{DDT}$

$\mathrm{p}, \mathrm{p}^{\prime}-\mathrm{TDE}$

$\beta$-Endosulfan

p,p'-DDT

Endosulfan sulfate

\section{Methodological Considerations}

As shown in Table 1, several of the pesticides determined in the cigarette blends were present in very low concentrations or could not even be detected. Calculation of transfer rates and of retention by filters could, therefore, not be done on individual substances, but had to be based on the total pesticides present. When determined in smoke, the total pesticide figures also include those substances which were not originally present in tobacco, but were formed by partial chemical degradation upon smoking. In some of the experiments, the cigarette blend was spiked with an additional amount of pesticides, i.e. approx. $10 \mu \mathrm{g} /$ cigarette per substance, applied by injection into
Table 1. Pestlcide residues (ppm) in cigarette tobacco blends.

\begin{tabular}{l|l|l|l|c}
\hline \multirow{2}{*}{ Component } & \multicolumn{4}{|c}{ Tobacco type } \\
\cline { 2 - 5 } & $\begin{array}{c}\text { Mary- } \\
\text { land } \\
\text { blend }\end{array}$ & $\begin{array}{c}\text { Vir- } \\
\text { ginia } \\
\text { blend }\end{array}$ & $\begin{array}{c}\text { Orien- } \\
\text { tal } \\
\text { blend }\end{array}$ & $\begin{array}{c}\text { Ameri- } \\
\text { can } \\
\text { blend }\end{array}$ \\
\hline$\alpha$-BHC & n.d. & n.d. & 0.16 & 0.08 \\
$\gamma$-BHC (lindane) & n.d. & n.d. & 0.35 & 0.21 \\
Aldrin & n.d. & n.d. & n.d. & 0.01 \\
o,p'-DDE & n.d. & n.d. & n.d. & n.d. \\
$\alpha$-Endosulfan & 0.02 & n.d. & n.d. & 0.04 \\
p,p'-DDE & 0.13 & 0.13 & 0.18 & 0.25 \\
Dieldrin & 0.02 & n.d. & n.d. & 0.04 \\
o,p'-TDE & 0.67 & 0.13 & 0.01 & 0.35 \\
Endrin & 0.015 & 0.03 & n.d. & 0.05 \\
o,p'-DDT & 0.20 & 0.15 & 0.30 & 0.51 \\
p,p'-TDE & 3.37 & 0.91 & 0.07 & 1.75 \\
$\beta$-Endosulfan & 0.05 & 0.03 & 0.05 & 0.15 \\
p.p'-DDT & 0.96 & 0.99 & 1.60 & 3.35 \\
Endosulfan sulfate & n.d. & n.d. & n.d. & n.d. \\
\hline
\end{tabular}

n.d.: not detected.

the cigarettes. The recovery rates of the injected pesticides from tobacco showed that the injection method was acceptable.

\section{RESULTS}

The average total pesticide transfer rate was $17 \%$ (Table $2)$; it appeared to be independent of the tobacco type (American blend, Maryland, Virginia, Oriental).

However, as shown in Table 3 and Figure 2, the percentage of retention by the cigarette filters depended on the efficiency of the filters used, according to the type of filter. The retention by the cellulose acetate filter II was comparable to the retention by the cellulose filter. The latter showed comparable retentions for both total pesticides and nicotine. In both the low and high pressure drop cellulose acetate filters, however, the pesticide retention is lower than the nicotine retention. The charcoal filter retained comparable proportions of pesticides to the cellulose and the cellulose acetate II filters, but proportionally more nicotine.

When cigarettes spiked with additional pesticides were used, it was found that the activated charcoal did not retain pesticides from the smoke stream. This observation is based on identical retentions by the plug-space-plug filters with empty vs. carbon-filled cavities (see Table 4). Pesticide transfer rates were observed to be higher in

Table 2. Mean transfer and retentlon of pesticides from various tobacco blends.

\begin{tabular}{lcc|c|c|c}
\cline { 2 - 5 } & $\begin{array}{c}\text { Ameri- } \\
\text { can } \\
\text { blend }\end{array}$ & $\begin{array}{c}\text { Mary- } \\
\text { land } \\
\text { blend }\end{array}$ & $\begin{array}{c}\text { Vir- } \\
\text { ginia } \\
\text { blend }\end{array}$ & $\begin{array}{c}\text { Orien- } \\
\text { tal } \\
\text { blend }\end{array}$ \\
\hline Transfer into the smoke (\%) & 13 & 12 & 12 & 13 \\
Total transfer (\%) & 17 & 16 & 16 & 17 \\
Retention by filter (\%) & 23 & 25 & 25 & 23 \\
\hline
\end{tabular}


Figure 2. Mean transfer of pesticldes and nlcotine and retention in various filter types.

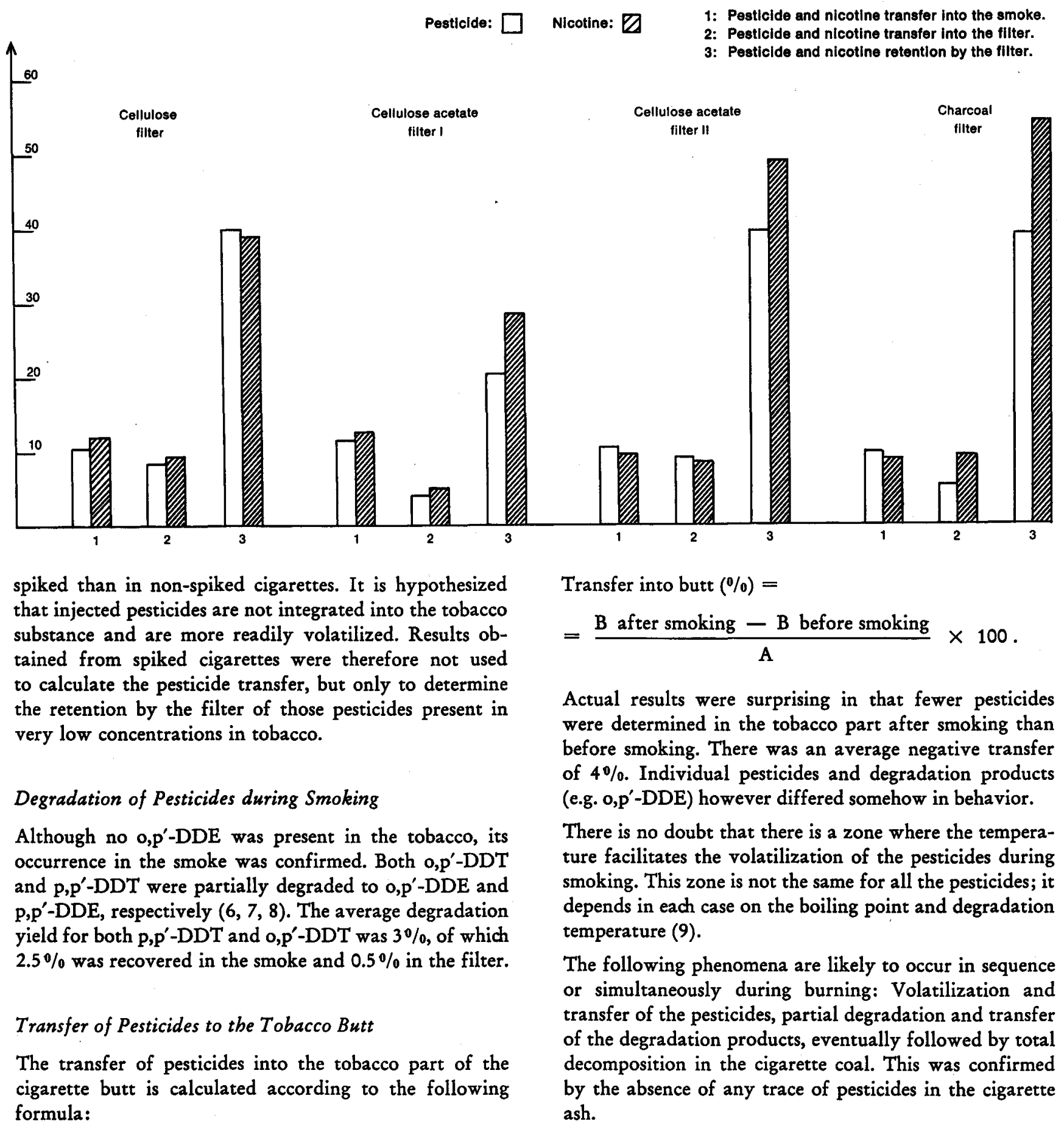

Table 3. Mean transfer of pesticides and nicotine and retention in various filter types.

\begin{tabular}{|c|c|c|c|c|c|}
\hline & & \\
\hline & & $\begin{array}{l}\text { Cellulose } \\
\text { filter }\end{array}$ & $\begin{array}{l}\text { Cellulose } \\
\text { acetate } \\
\text { filter I }\end{array}$ & $\begin{array}{l}\text { Cellulose } \\
\text { acetate } \\
\text { filter II }\end{array}$ & $\begin{array}{c}\text { Charcoal } \\
\text { filter }\end{array}$ \\
\hline Pesticide transfer into the smoke & $(\%)$ & 11 & 13 & 11 & 10 \\
\hline Nicotine transfer into the smoke & $(\%)$ & 15 & 15 & 9 & 8 \\
\hline Pesticide transfer into the filter & $(\%)$ & 7 & 3 & 7 & 6 \\
\hline Nicotine transfer into the filter & $(\%)$ & 9 & 5 & 8 & 9 \\
\hline Pesticide retention by cigarette filter & $(\%)$ & 39 & 19 & 39 & 38 \\
\hline Nicotine retention by cigarette filter & $(\%)$ & 38 & 25 & 47 & 53 \\
\hline
\end{tabular}


Table 4. Pesticide retentlon by charcoal filter.

\begin{tabular}{l|c|c}
\hline \multirow{2}{*}{ Component } & \multicolumn{2}{|c}{ Retention (\%) } \\
\cline { 2 - 3 } & $\begin{array}{c}\text { Cavity with } \\
\text { charcoal }\end{array}$ & Empty cavity \\
\hline p,p'-DDT & 39 & 39 \\
p,p'-TDE & 39 & 38 \\
o,p'-DDT & 39 & 39 \\
O,p'-TDE & 38 & 38 \\
p,p'-DDE & 34 & 35 \\
o,p'-DDE & 36 & 35 \\
\hline Mean value & 38 & 37 \\
\hline
\end{tabular}

\section{SUMMARY}

The transfer during smoking of pesticides contained in tobacco into the smoke and the filter of cigarettes was investigated.

The overall transfer into the mainstream smoke was $17 \%$. It was found to be independent of the type of the tobacco blend (American, Maryland, Virginia and Oriental).

The pesticide retention of the following four filters was investigated: cellulose filter, cellulose acetate filter with low and high pressure drop, and a charcoal filter, characterized by nicotine retentions of $38 \%, 27 \%, 48 \%$ and $54 \%$, respectively. The corresponding pesticide retentions found were $40 \%, 21 \%, 39 \%$ and $38 \%$, i.e. lower than the nicotine retention in the cellulose acetate, and significantly lower in the charcoal filter.

A $3 \%$ degradation of $p, \mathrm{p}^{\prime}-\mathrm{DDT}$ and $\mathrm{o}, \mathrm{p}^{\prime}-\mathrm{DDT}$ contained in tobacco to $\mathrm{p}, \mathrm{p}^{\prime}-\mathrm{DDE}$ and $o, \mathrm{p}^{\prime}-\mathrm{DDE}$ respectively, was also observed. The pesticides initially contained in the tobacco part of the cigarette butt decreased during smoking. This appears to be the result of some initial condensation of substances carried through by the smoke stream (as indicated by the presence of pesticide degradation products), followed by strong desorption during the very last puffs.

\section{ZUSAMMENFASSUNG}

Es wurde untersucht, inwieweit im Tabak enthaltene Pestizide während des Abrauchens in den Rauch und in den Filter der Cigarette übergehen.

Es zeigte sich, daß der Gesamtübergang der Pestizide in den Hauptstromrauch 17\% ausmacht und von der Art der Tabakmischung („American blend“-, Maryland-, Virginia- und Orient-Tabak) unabhängig ist.

Die Pestizidretention folgender vier Filterarten wurde untersucht: Cellulosefilter, Celluloseacetatfilter mit niedrigem und hohem Zugwiderstand und Kohlefilter. Die Nikotinretention dieser Filter betrug 38, 27, 48 bzw. $54 \%$. Für die Pestizidretention ergaben sich die Werte von $40,21,39 \mathrm{bzw} .38 \%$, d. h. sie war im Celluloseacetatfilter niedriger und im Kohlefilter erheblich niedriger als die Nikotinretention.

Es wurde auch beobachtet, daß sich im Tabak enthaltenes
p,p'-DDT und o,p'-DDT zu 3\% zu p,p'-DDE bzw. o,p'DDE abbaut. Die anfangs im Tabakteil des Cigarettenstummels vorhandene Pestizidmenge nahm während des Abrauchvorganges ab. Dies scheint durch eine anfängliche Kondensation von Substanzen bedingt zu sein, die durch den Rauchstrom transportiert werden (was auch das Vorhandensein von Pestizidabbauprodukten zeigt); mit den letzten Zügen erfolgt anschließend eine starke Desorption.

\section{RESUME}

Nous avons procédé à une étude sur le transfert et la rétention des pesticides présents dans le tabac lors du fumage.

Il s'avere que le taux de transfert total des pesticides dans la fumée principale ne dépend pas du type de mélange utilisé (Américain, Maryland, Virginie et Orient), et est égal à $17 \%$.

Pour étudier la rétention des pesticides, nous avons com-

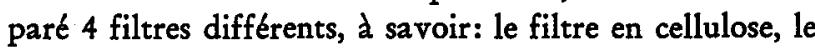
filtre en acétate de cellulose à faible et haute résistance au tirage, et le filtre à charbon. Les résultats obtenus sont de $40 \%, 21 \%, 39 \%$ et $38 \%$, résultats que nous pouvons comparer à ceux de la rétention de la nicotine par ces mêmes filtres, à savoir: $38 \%, 27 \%, 48 \%$, et $54 \%$.

Nous avons constaté une dégradation de $3 \%$ de p, $\mathrm{p}^{\prime}$-DDT et $o, p^{\prime}-D D T$ présents dans le tabac en $p, p^{\prime}-D D E$ et $o, p^{\prime}-D D E$ respectivement. En étudiant ce que deviennent les pesticides initialement présents dans la partie tabac du mégot, nous avons constaté une diminution de leur teneur après fumage, ainsi que la présence de produits de dégradation. Ceci permet de conclure à une déposition initiale dans cette partie de la cigarette, suivie d'une forte désorption lors des dernières bouffées.

\section{REFERENCES}

1. Coresta, Standard Method Nr. 10: Machine smoking of cigarettes, determination of crude and dry smoke condensate; Coresta Information Bulletin 1969-1, 14-33.

2a. Coresta Recommended Method No. 2: Determination of organochlorine pesticide residues in tobacco; $\mathrm{Co}$ resta Information Bulletin 1974-2, 23-30.

2b.Coresta-Methode Nr. 2: Methode für die Bestimmung von Rückständen an Organochlor-Pestiziden in Tabak; Beitr. Tabakforsch. 8 (1975) 109-111.

3. Coresta Standard Method No. 13: Determination of alkaloid retention by cigarette filters; Coresta Information Bulletin 1969-2, 9-20.

4. Nesemann, E., R. Schröder and F. Seehofer: Methoden zur quantitativen Bestimmung von Insektiziden in Tabak und Tabakrauch, I. Mitteilung: Zur Bestimmung von Organo-Chlor-Insektiziden; Beitr. Tabakforsch. 4 (1968) 182-188.

5. Hoffmann, D., and G. Rathkamp: Chemical studies on tobacco smoke, V. Quantitative determination of chlorinated hydrocarbon insecticides in cigarette to- 
bacco and its smoke; Beitr. Tabakforsch. 4 (1968) 201-214.

6. Chopra, N. M., John J. Domanski and Neil B. Osborne: Systematic studies on the breakdown of $\mathrm{p}, \mathrm{p}^{\prime}$ DDT in tobacco smokes; Beitr. Tabakforsch. 5 (1970) 167-174.

7. Chopra, N. M., and John J. Domanski: Systematic studies on the breakdown of p,P'-DDT in tobacco smokes, III. Isolation and identification of the nonvolatile degradation products of $p, p^{\prime}-D D T$ in $p, p^{\prime}-$ DDT-treated tobacco smokes; Beitr. Tabakforsch. 6 (1972) 139-143.

8. Chopra, N. M., J. T. Thekkekandam: A mechanistic study on the formation of the non-volatile degradation products of $p, p^{\prime}-D D T$ and $p, p^{\prime}-T D E$ in $p, p^{\prime}-$ DDT- and P,P'-TDE-treated tobacco smoke; Beitr. Tabakforsch. 7 (1973) 88-92.
9. Lendyay, Andrew T., and Tibor S. Laszlo: Cigarette peak coal temperature measurements; Beitr. Tabakforsch. 7 (1974) 276-281.

10. Hengy, $H_{\text {, }}$, and $J$. Thirion: The determination of malathion residues in tobacco and tobacco smoke condensate; Beitr. Tabakforsch. 5 (1970) 175-178.

11. Hengy, H., and J. Thirion: The determination of Thiodan and Thiodan sulphate on tobacco and in smoke condensate; Beitr. Tabakforsch.6(1971) 57-61.

Authors' address:

Tabacofina S.A., Service de Recherche, 61 , route de Chêne,

CH-1208 Geneva, Switzerland. 